\title{
JOINT WORKING GROUP IMPLEMENTATION: FRENCH EDUCATION DIPLOMACY ON INDONESIA YEAR 2012-2016
}

\author{
Fenny Maria Christien \\ International Relations, Universitas Kristen Indonesia, Jakarta, \\ Indonesia \\ vennimariachristien@gmail.com
}

\begin{abstract}
The progress of globalization has made every country to cooperate internationally to fulfill its national interests. Indonesia sees opportunities from France as a country that has the more advanced technology from Indonesia. In education, France is a country that has the best system. France saw a joint research opportunity to do both so that both of them agreed to make cooperation conducted by the Ministry of Research and Higher Education (Kemristek Higher Education) at the French Embassy in the meeting of the Joint Working Group in the field of Research and Higher Education. Until the eighth meeting from 2009 to 2016, continue to discuss whatprograms will get done. But in reality, in 2012 until 2016, participants from the scholarships given by Kemristek Dikti decreased. From the decline, it gets seen that the delay factor of fund given to the scholarship recipients makes the students feel hampered in doing their activities, besides the lack of socialization of this scholarship which makes the students who want to seek for learning to France do not know about this scholarship program
\end{abstract}

Keywords: Joint Working Group, Education, Indonesia, France, Cooperation

DOI: 10.33541/sp.v19i2.1648

Sociae Polites : Majalah Ilmiah Sosial Politik

Faculty of Social and Political Science, Universitas Kristen Indonesia

ISSN 1410-3745 print/ ISSN 2620-4975 online

Volume 19, Number 2 (July - December 2018)

Pages 105-120 


\section{Introduction}

Education is an essential thing in human life. Every human being has the right to gain and develop knowledge in education. Education gives man to know, paving the way in his career and building his character. Education is a human effort through guidance, teaching, and training.

To get the right human resources also need to be supported with a mixed education and seen from some countries that began to improve the education system so that every community can receive an education. Starting from the addition of facilities to learn to teach, subsidize, and also other ways traveled by the Government so that every community without exception can enjoy education.

Indonesia, as a developing country, certainly wants to keep trying to be able to advance the state. Indonesia belongs to the most population in the world that makes Indonesia very possible to compete with other countries. But many human resources are not capable of changing anything if human resources do not have good quality in the international world. Moreover, Indonesia has entered into the ASEAN Economic Community (AEC) that makes Indonesia have the will to compete with other countries.

Based on the intensity of cooperation in high education and research, Indonesia, through the Ministry of Technology and the Higher Education Republic of Indonesia, conducted cooperation through the annual meeting of Joint Working Group Indonesia - France in Research and Higher Education. The annual meeting until 2016 has done eight sessions in different places each year, discussing the development of several bilateral cooperation programs in Indonesia and France to create new programs and to carry out bilateral cooperation is more effective.

Joint Working Group is done by every country when doing cooperation as well as in problems and finds the best solution for both parties concerned. Thus, the Joint Working Group meeting can be said to be the Indonesian and French way of diplomacy. This research will discuss the implementation of the Joint Working Group Indonesia - France in Research and Higher Education as a form of French education diplomacy on education in Indonesia in 2012-2016.

The type of research used by authors is descriptive analysis. The research model used by the authors is library research through data collection by studying some literature related to the issues reviewed.

\section{Education System in Indonesia}

During this time, the Indonesian government focused only on the student graduation rate. The quality of education is not yet a government priority. While the number of students participating without being accompanied by the provision of good quality of teaching and facilitate it will not have much impact on the quality of the individual.

Education level in Indonesia, one to pursue higher education, beginning with kindergarten, is continued to primary and secondary school that is under the auspices of the Ministry of Primary and Cultural Education. While higher education is under the auspices of the Ministry of Technology Research and Higher Education, there is also primary, intermediate, and high school, which is religiously based and administered by the Ministry of Religious Affairs (CNN Indonesia 2016).

One of the ways the government takes to improve education in Indonesia is to create a School Operational Assistance Program (SOAP). SOAP is a government program 
for the provision of non-personal cost financing for the first unit of primary and secondary education as a form of compulsory learning program of nine years. SOAP prioritized for non-personal operational expenses. This phenomenon gets done as a form of easing the public burden on education financing to study nine years of quality. The goal of the SOAP program is all students in Elementary School (ES)/ Madrasah Ibtidaiyah (MI) and Junior High School (JHS)/ Madrasah Tsyanawiyah (MTs), including Open Secondary Schools and the Self-

Learning Activities Center organized by the public and private sector in all provinces in Indonesia (TNP2K 2012).

\section{Education System in France}

France is a country that implements compulsory learning systems. Unlike the methods and tiers in Indonesia, in France, every six-year-old child must enter an elementary school consisting of three stages:

1. The first stage (Preparatory Education/ Cours Preparatory) of class 11, which is equal to Grade 1 Elementary School.

2. The second stage is (Basic Education) which has two ranks (First Year Basic Education/ Cours Elementaire Premiere Annee) as Grade 10 which is equivalent to Grade 2 Elementary School, and (Second Year Basic Education/ Cours Elementaire Deuxieme Annee) as Grade 9 which is equal to Grade 3 Elementary School.

3. The, the third stage (Advanced Basic Education) consists of 2 tiers (First Year Continuing Education/ Cours Moyen Premiere Annee) as class 8 which is equal to Grade 4 Elementary School, and (Second Year Advanced Basic Education/ Cours Moyen Deuxieme Annee) as Grade 7 which is equivalent to Grade 5 ELEMENTARY School. So, elementary education in France consists of five levels. (Hoed 2008, 7-9).

After Elementary School, was continued to a secondary education consisting of two stages, namely the College, equivalent to Junior High School but for four years, and Lycee equivalent to Senior High School for three years. In Lycee, there are three levels, namely Seconde Class 2, Premiere Class 1, and Terminal. When the child is 18 years old must take a national final exam called Baccalaureat. Uniquely in France, there is such a thing as a Senior High School called the Grandes Ecole, providing education for teachers, lecturers, and researchers in various fields not only work as a teacher but can work outside of school, including in bureaucracy and business. After passing the stage, then proceed to Universities.

In terms of education, France put the country in the dominant position that is the role of the Government in the field of knowledge from the basic level to the high level is very large, the state pays all public education institutions, teachers, and administrative personnel. Even countries, by law, regulate education programs as well as curriculum from primary to higher education. However, in May 1968, there was a change due to the student revolution in college life. By the event, the university was directed by a council (Conseil D'universite) whose members consist of teachers, administrative officers, and students. The President heads every Government college. Regulatory affairs are managed by a Rector who overtakes the organizational problems of aregion.

After the event "may 68" from 1970 in the entire area of Paris and the 
surrounding areas, there were 13 universities. Several public universities get established in fields, and private universities in France were few (about 10-15), which were very small in higher education in France (Ibid, 13-16). Higher education in France follows European Union systems and rules; a diploma certificate is taken as a reference academic year or academic semester validated since admission to higher education institutions and their deposits in the European Credit Transfer System (ECTS):

$$
\begin{array}{ll}
\text { 1. } & \text { Licence }(\mathrm{S} 1)=6 \text { Semester }=180 \text { ECTS }(\text { SHS }+3 \text { years }) \\
\text { 2. } & \text { Master }(\mathrm{S} 2)=10 \text { Semester }=300 \text { ECTS }(\text { SHS }+5 \text { years }) \\
\text { 3. } & \text { Doctorat }(\mathrm{S} 3)=16 \text { Semester }(\text { SHS }+8 \text { years }) .(\text { France2011). }
\end{array}
$$

The French government made a lot of subsidies in the field of education, transportation infrastructure, and some assistance for French students and international students so that the cost of education in France is affordable, and the government has issued up to $23 \%$ of the state budget for education. The importance of public education will continue to hone its ability to compete positively because of an excellent appreciation gained by someone with a high school while workinglater.

\section{Action Plan Joint Working Group at First to EighthMeeting}

At the first meeting of the title on 13 November 2009 in Bali, they were discussing the deal and action plan that will get undertaken in cooperation in this field of research and higher education. At the first meeting, it explained that the Government of Indonesia and the French government agreed to cooperate in mobilizing the cooperation program that will start in the year 2010. In the meeting, it decided that Indonesia received the support of funds to run the Joint program combined program between the Ministry of National Education and the French embassy based on the agreed Memorandum of Understanding (MoU) of 60 candidates for the master's degree. In terms of scholarships, Indonesia also supports the delivery of the best Indonesian students to the program of excellent learning. Between Indonesia and France also sought to agree on exploring the possibilities of developing cooperation in the study of arts and culture. The Indonesian Government encourages lecturers to promote Indonesian culture in French universities, and of course, the French government will facilitate it. ( $1^{\text {st }}$ Joint Working Group 2009)

As a first meeting, this was the earliest form of diplomacy between the Ministry of Research, Technology \& Higher Education, and France, the type of educational diplomacy conducted by France through a meeting, which resulted in agreements and policies between Indonesia and France. In doing diplomacy, French education puts the interests of its people by expanding the cultures to make France a local community.

This educational diplomacy is one of the strategies that France has to see the global situation that is expanding and expanding. France considers that with the widespread extent that the boundaries of the country can get utilized to reach the national interests of the country so that France does diplomacy to other countries such as Indonesia. But not only for France, has Indonesia seen the era of globalization as an opportunity to achieve its national interests by expanding and improving education.

The second meeting performed on November 30, 2010, in Paris discussed the Double Degree Programme, one of which was Indofrancotech (INDOTECH) Programme, which successfully involved 49 lecturers from Indonesian Polytechnic to follow the second year of his master's degree at the University of France. Indonesia and France agreed that the program should continue with the same flow. The Indonesian 
(Ministry of Research, Technology \& Higher Education) will provide scholarships to the student that include books, living expenses in France as well as travel expenses. At the same time, the French party will finance intensive French courses in advance and include student insurance during students in France; this scholarship in 2011 is available for 60 scholarship recipients.

In cooperation in the Indonesian field of research agreed to establish a doctoral network to shoot joint supervision of Ph.D. (Doctorate en Cortutelle) for Indonesian academics and fund up to 25 scholarships for 2011-2012Using the same scheme as Indofrancotech. Besides, both sides agreed that the academic exchange should get strengthened until Indonesia cooperated with several French universities in a system to invite Indonesian lecturers who were studying doctors at the University of Indonesia to spend 2 to 4 months in a French laboratory and also both willing to exchange information about academics.

In addition to this second meeting, Indonesia and France made two exchange agreements to encourage and facilitate the action plan of the Joint Working Group Indonesia and France, namely:

a. They are exchanging experience in the framework of modernization of Indonesian research laboratories.

b. Both sides realized the importance of training to the head of the laboratory then held a general workshop in Indonesia in May or June 2011 for the head of the laboratory. The workshop will focus on the development, equipment, and maintenance of human resources for the modernization of Indonesian research laboratories.

c. They hoped to make strategic plans for modern research laboratories, which include human resources and equipment in their respective universities.

d. They are exchanging experience in vocational higher education.

e. France has extensive experience in the field of quality guarantors higher at various degrees from high school to technical colleges and technical schools. Based on the record, both sides will examine the possibility of making a training program for Indonesian polytechnic directors, and the program will start from July 2011 ( $2^{\text {nd }}$ Joint Working Group 2010).

The process of education diplomacy conducted by France to Indonesia enables collaboration between the two to make with this cooperation strengthening the relationship of both. Seen from the existence of Sandwich Like program for lecturers, there is a cooperation to produce comparisons between education in Indonesia and France. A comparison of both can be seen by lecturers who researched in France for $2-4$ months.

At a third meeting held on 15-17 November 2011 in Manado, France helped Indonesian students who wish to attend French courses in Indonesia. Especially for those interested in education in France because, based on the French government regulations that students who follow school in France must have studied French and have a minimum DELF certificate at B2 level. DELF or Diplôme D'etudes en Langue Française is a French certificate of proficiency organized by the $\mathrm{C}$ e $\mathrm{n} \mathrm{t} \mathrm{r}$ e International d'études pedagogique under the authority of the French Ministry of Education. In Indonesia, only IFI entitled to conduct DELF certification exams. DELF level: A1 for base Level, A2 for advanced base Level, B1 for intermediate Level, B2 for advanced Intermediate Level. Meanwhile, after level B2, there are two levels, namely DALF C1 and C2: C1 for Advanced Level, C2 for 
autonomous Level (French, 2017).

The discussion continued on programs that have gotten done as an extension and by seeing the achievement of the action plan last year as in the master's application of the agreement to prepare scholarships for Indonesian students. Explanation of the program mentioned at the previous meeting in Bali about the FastTrack Bachelor Master Doctorate Program is a scholarship given to young Indonesian students who have completed their master's degree will get continued in his doctoral degree.

Two financing schemes are given by Indonesia, namely: the Flagship Scholarship Planning Foreign Cooperation, which provides life support in France as well as the cost of travel to France and the Excellent Scholarship of the Ministry of Research and Higher Education (MRHE) that provides money book, value and support life in France and the cost of travel to France. While France will finance tuition and insurance and visa gratification throughout the year during the students are in France. In France, a bachelor's degree consists of 3 years of study (L1, L2, and L3). After completing a bachelor's degree, a student can advance to two years of subsequent studies (M1, M2) to obtain a master's degree and differ from in Indonesia, students to get a bachelor's degree must complete within four years and two years to complete the master's degree.

Unlike the previous year in the program, Sandwich Like Developments, w h i c h previously Indonesian lecturers at least 2 to 4 months in France, experienced a growth of 2 to 5 months to be settled and spend time in France. Both sides agreed to continue making various polytechnic inauguration programs and also in Vocational High School (VHS), which $g$ e $t$ realized with the universities/companies of Indonesia and France. In addition to higher education and research, Indonesia and France made a deal with the INDOART program, collaboration in art and culture higher education. This agreement covers the continuation of business making programs so that students can have double experience from the Art Institute of Indonesia and the French Art Institute. Indonesia will finance intensive sessions in France, and Indonesia in the art discipline of the French Institute in Indonesia will facilitate the workshop of French artists at the Indonesian Institute of Arts. ( $3^{\text {rd }}$ Joint Working Group 2011)

The standardization performed by France to accept students and lecturers who are conducting education and research in France has a minimum certificate of the $\mathrm{F} \mathrm{r}$ e $\mathrm{n} \mathrm{c} \mathrm{h}$ language level to have. That gets done as an effort to expand the French culture towards Indonesian society. With this achievement, the national interests of France said to succeed through international cooperation.

The next meeting was the fourth meeting held on 10-11 October 2012 in Toulouse. For the development of magister and doctoral programs, both sides agreed that their cooperation would focus on the next subjects:

1. Environment, Resources, Sustainable and Urban Development.

2. Treatment, Public Health, and Human Biological applied to Health.

3. Science of Technology, Energy, and Engineering.

4. Political Science, Economics, and Law.

5. Social and Human Sciences, art and tourism

Later at this meeting discussed the development of programs that have gotten agreed at the previous meeting in Manado ( $4^{\text {th }}$ Joint Working Group 2012).

The fifth meeting held on 10-11 October 2013 in Surabaya. This fifth collaboration was a remarkable success from 61 French institutions, and 84 Indonesian institutions took part in the event. Not only the university, but also the research center, the French State Technical Service, Polytechnic, VHS, and 7 French companies participated in the 
discussion in Surabaya. In addition to discussing the developments of the programs that have been agreed at the previous meeting, in this fifth meeting there are eight focuses of group discussions in the fifth Joint Working Group of Indonesia and France, namely:

1. Ocean Engineering.

2. Engineering.

3. Health Sciences.

4. Management, Economics, Law, and Public.

5. Disaster Management.

6. Social, Humanities and Politics, Including Tourism and Arts.

7. Agriculture and Forestry.

8. Vocational and Polytechnic.

As a form of development in the era of education globalization, this cooperation adds to the scholarship given to students and lecturers in other fields, as listed above in 8 points. That gets done for the efforts to expand the knowledge and research exchanges that do both.

At the sixth meeting held on June 10-11, 2014 in Lille involved 60 French institutions and 41 Indonesian institutions and such last year's conference in Surabaya, not only the universities that participated but also research, Polytechnic, Vocational Institutions, ministries, and even companies. They discussed the development of an agreed-upon program in the previous meeting with little improvement. As with the scholarship at the master level, both parties agreed to increase the number of education given this year from the number of learning in previous years. Not only add scholarships but in the program DDIP Plus in the field of tourism focusing on the study of tourism and hospitality management, hospitality marketing, restaurant, and food management, planning, and development of tourist and event planning.

By realizing the need to strengthen academic mobility as in the program in previous years of Sandwich Like, at an agreement at the earlier meeting that Indonesian lecturers invited to spend two to five months in France on expanding the knowledge of Indonesian lecturers with the education system that France did. For this year, the two sides agreed to strengthen the program by inviting Indonesian lecturers to spend three to nine months in France. Not only Indonesian lecturers, with this program that strengthens cooperation between Indonesian and French universities, so French lecturers can visit Indonesia about three to nine months ( $6^{\text {th }}$ Joint Working Group 2014).

The seventh meeting was held from 9 to 10 March 2015 in Medan. At the meeting, there were 29 high school and French research institutions and 47 institutions of higher education and research in Indonesia. Referring to the programs that get agreed in the previous meetings, of course, this meeting will discuss developments and changes for each application that is considered essential and influential.

In this year, there is the addition of scholarship given by the Ministry of Research and Higher Education, which is up to 45 scholarships, which from previous years reached 25 education award. At the meeting this time discussed the developments and schemes of several supporting programs in the scholarship program for Master's degree and doctoral degrees as a supporter of academic exchange:

1. Program Hubert Curien-Nusantara (PHC)

The program allows the Joint Research team to answer the proposal request, which was launched every two years by the Ministry of Research and Higher Education and the France Embassy. Research applicants can come from research agents or universities. The research project to be selected will be funded for two 
years to support the mobility of researchers in the chosen plan.

2. Scheme of Academic Mobility and Exchange (SAME)

This program allows researchers from both sides to conduct joint research activities for three months in one of the universities of Indonesia or France. The exchange must get made within the framework of inter-university agreements. This program aims to produce even more international scientific publications so that more literature provided to be able to support the next study.

3. Enhancing International Publication (EIP)

The scheme of the program allows Indonesian lecturers to perform their Ph.D. at the University of Indonesia and getting invited to spend between 3 to 9 months at the French higher education and research institutions and allow French lecturers to get invited to spend 3 to 9 months at high education institutions and Indonesian research. Applicants must undoubtedly apply to the Ministry of Research, Technology, and Higher Education and to IFI ( $7^{\text {th }}$ Joint Working Group 2015).

The eighth meeting was held on 5-6 April 2016 in La Rochelle, which attended by participants from 30 institutions of higher education and French research and 41 institutions of higher education and research in Indonesia. Along with the participants of the higher education and polytechnic, there are also representatives of the Ministry of Maritime Coordinator and resources RI and research institutes of the two countries as well as representatives of business (private companies).

In each meeting, discussing programs agreed upon, the approved plan will be reviewed at the upcoming session to see the development and success and effectiveness of the program. At this meeting, the two sides discussed the proposed establishment of the Joint Committee of both countries of the country of Indonesia, where the Joint Committee will then aim to be responsible for evaluating the activities and programs that agreed in each JWG meeting.

After discussing the programs agreed, the two parties continue to strive to expand and improve from any program agreed to increase the number of exchanges of lecturers and researchers between the two countries through the programs made, increasing the number of students of Ph.D., Masters, and scholars. Increasing the number of consortium in higher education and research of both countries, increasing the number of Indonesian sponsors who learn French and vice versa, increasing the number of lecturers and researchers from both countries, and also improve the business/industry involved in the cooperation of French Indonesia. ( $8^{\text {th }}$ Joint Working Group 2016).

\section{Joint Working Group Implementation in2012-2016}

At the first Joint Working Group meeting, the eighth was found a result indicating that the implementation of the meeting did not entirely run effectively. It can get noted in the following table:

Table 1. Scholarship Participant Numbers

\begin{tabular}{|c|c|c|}
\hline Year & Total Students & Total Lectures \\
\hline 2012 & 228 Person & 39 Person \\
\hline 2013 & 237 Person & 54 Person \\
\hline 2014 & 232 Person & 18 Person \\
\hline
\end{tabular}




\begin{tabular}{|c|c|c|}
\hline 2015 & 214 Person & 26 Person \\
\hline 2016 & 161 Person & - \\
\hline
\end{tabular}

Source: Anton, Arini, Editha. 2017

In the table above is the number of numbers of Indonesian students and lecturers who participated in scholarships from the JWG Indonesia France program from 2012 to 2016. There is a decline in $\mathrm{t} \mathrm{h}$ e $\mathrm{n}$ a $\mathrm{m}$ e of participants conducted by $\mathrm{t} h$ e Ministry of Research, Technology and Higher Education, and the French embassy. However, in each meeting, the programs agreed on the increase. Still, indeed the number of participants who qualify from $\mathrm{t} \mathrm{h}$ e stipulated conditions such as administration, language skills, and other terms do not meet the quota that has been prepared by the Ministry of Research, Technology and Higher Education, and the French embassy.

From the table above, we can conclude that the implementation of JWG in the first meeting of up to eight French and Indonesian does not always produce good results. That can get demonstrated by the decline in the number of human resources in the scholarship program. It said that the program that carried out in the scholarship from the Ministry of Research, Technology, and Higher Education and the French Embassy is not entirely successful if viewed from the target participant that corresponds to the target and what to expect. The program is quite successful, looking at the fact that every year there are students and lecturers of Indonesia who return to the study period so Indonesia could have more qualified human resources that can build the country. That gets viewed from the number of alumni who have conducted higher education in France, which get netted in the French Association of Alumni of Indonesia (FAAI), which is an Indonesian alumni association who has studied in France. The initial idea of FAAI was launched in 1980 by Indonesian alumni and diplomats. With the support of the French Embassy in Indonesia, FAAI became an organization based on the law. The association based on the principle of equality, which combines various sectorial and professional competencies, to improve access and develop the network of potential resources among its members (Indonesia, 2017).

The FAAI alumni are not only graduates from scholarships conducted by the Ministry of Research, Technology and Higher Education, and the French embassy only but also from other education provided by another ministry and, of course, by the French government. Therefore, the programs of JWG are essential to add scholarship participants to be able to follow the education in France apart from other scholarships.

This international cooperation conducted by Indonesia and France get solely based on the national interests of each country. Indonesia who expects to get qualified human resources, sees opportunities from France, which is one of the countries that want and has modern technology, has good education and research so that Indonesia is interested in making cooperation in the field of education and research. It is a form of the Indonesian government strategy to be able to have graduates, masters, and doctors to fix Indonesia.

Indonesia, who has many human resources, can not affect Indonesia's progress if it is not able to be appropriately processed by its human resources because a country has to be managed by its people to be a developed country. For France, they saw abundant natural resources as well as Indonesia's unique and diverse culture that made France interested in establishing cooperation in research and information exchange by sending lecturers and students to do study visits. Not only that, but France also aims to expand its culture by creating information centers and culture of FAAI scattered in several major cities in Indonesia. 
In FAAI, the people of Indonesia can learn French and know about the cultures in France. At this time, even IFI made a French stall, which is a place of information on French culture made in several colleges in Indonesia. French stalls not only provide information about French culture but also about study in France and scholarships offered by the French government. It provides books, CDs, DVDs, French magazines, and brochures on FAAI activities, French education, and awards. French stalls thrive in universities and polytechnics throughout Indonesia. Since the year 2012 and until now has been 35 French stalls opened in universities spread across Indonesia (IFI, 2016).

Indonesian and French cooperation began with the formation of FAAI until now. FAAI is scattered in several major cities in Indonesia and survives at this moment shows that the results of Indonesia's French cooperation succeed. The enthusiasm of the Indonesian Society of French culture brought FAAI to the present.

This collaboration went smoothly, thanks to the good relations that get woven between Indonesia and France. Good relations both facilitate diplomats in negotiating to form an agreement that produces programs in the JWG Action plan on each meeting. Bilateral diplomacy undertaken by both countries is undoubtedly the opening of the road between the two to make cooperation in other areas.

In the past, France is very famous for its tourism that attracts foreign tourists, thanks to its unique beauty and culture. It makes Indonesia cooperate in the tourism field, not only tourism and social education, but in France also famous since the advancement of technology so that it has a piece of useful knowledge in the field of engineering. The remarkable cooperation between Indonesia and France in the field of education gets seen with so many scholarships that France has given to Indonesia to make bilateral diplomacy between the two countries in its diplomatic is not less critical with other issues such as defense, security, andothers.

In the development of a modern era, students in each country competing to do their high education to look for the best universities in their field not only in education also in the world of work. Globalization will not always produce a positive thing, if not be encouraged by a good strategy. Like Indonesia in the ASEAN Economic Community (AEC), if Indonesia does not have an excellent approach to regulate its human resources and natural resources, Indonesia will be lagged away from other ASEAN countries. With the lag, it makes Indonesia challenging to manage its state. A stable country can be seen from its economy, while the economic development based on workforce skills in maintaining its natural resources. For developing countries such as Indonesia need to stabilize its engineering to avoid possible bending, poverty, and even hunger.

JWG is one of the strategies made by the Government of Indonesia in the care of globalization in higher education and cooperation in Indonesia with other countries AEC. This study explains that Indonesia and France consider education is a very noteworthy thing as a deciding factor for the progress of the state welfare, also national development. One of the reasons is because the human resources that have a high education as a quality asset of Labor have broad thinking and innovations that can get implemented to fix the country. Indonesia and France agreed to continue to build quality human resources and mutual relations from both to achieve their respective national interests.

The programs that have been agreed in the JWG positively impact the Indonesian students, especially those who have an interest in France to be able to follow higher education in France at an affordable cost so as not only for people who can get a highquality education. However, the programs in JWG have not been entirely successful if the number of participants continues to decline; it is necessary to review the decline of 
participants. Of course, the fall caused by several factors presented by alumni who have received scholarships such as the delay of funds they received so that the participants must fulfill the cost of necessary needs with his money before replacing by the Ministry of Research, Technology, and Higher Education. The delay in remittance of funds to the scholarship recipients due to the Indonesian financial system, which is in the process of improvement since the beginning of the government of Susilo Bambang Yudhoyono 2009 Scholarship Fund is dependent on the expenditure of State Budget Fund has a long bureaucracy in the process of disbursement. The scholarship recipient can receive a remittance of about $2-3$ months after being in France so that the scholarship the recipient must prepare the reserve money to be able to survive and perform his education and continues to work to improve the State Budget Financial system in the disbursement of scholarship funds. The Indonesian government has created an institution that can help facilitate Indonesian students in seeking domestic or overseas scholarships.

\section{General Service Agency (GSA)}

GSA is an institution in $\mathrm{t} \mathrm{h}$ e government environment that formed to provide services to the community in the form of goods/services sold without prioritizing profit and in conducting its activities based on the principle of efficiency and productivity. In its financial management, GSA got the flexibility of freedom to implement healthy business practices to improve service to the public, as an exception to the state's general financial management provisions. Government agencies are executing the GSA pattern at operational. The institution can be derived from and domiciled on various echelon (structural) or non-echelon (non-structural) levels. (Kemenkeu, 2006)

GSA made to reduce bureaucracy and also improve the quality of government services to the public, as stipulated in Government Regulation No. 23 of 2005 on public Service agency financial management. Under article 14 of the Government's regulations, GSA's income, whether derived from the State Budget and GSA operations, is reported as the non-government income tax of Ministry institution or state income non-governmental tax (Batan, 2005).

The funds by the Ministry of Research, Technology, and Higher Education late for a scholarship get issued late with the cause of the length of the bureaucracy process, which makes it difficult for funds to get melted following time. The way of fund management through this GSA by the Ministry of Finance, especially in scholarship funds to LPDP, is the right solution in making funds issued by the LPDP faster than the scholarship fund Ministry of Research, Technology, and HigherEducation.

With the difference in data management between LPDP and the Ministry of Research, Technology, and Higher Education due to the Ministry of Research, Technology and Higher Education fund derived from APBN and only exit in 2 times a year (around February-April and September-December), allowing a delay in March-April. The LPDP Scholarship fund gets derived from the perpetual funds managed by the GSA, which is a deposit fund for the budget of the State Budget of $20 \%$.

\section{Result of JointWorking Group}

Indonesia and France conducted cooperation with the form of the Joint Working Group as educational diplomacy conducted by France. France is more using community and government instruments so that the direction of the French education diplomacy leads 
to the expansion of culture and also in strengthening its contribution to international research and spreading innovation policy to support the strategy of French influence in the global world.

Cooperation done by Indonesia and France can be said to be successful when viewed from the French graduates that return to Indonesia and work to use the education and knowledge in national development. On the other hand, if seen from the target made in the JWG action plan from the first meeting to the eighth cannot be said successfully. The success of the scholarship is because several factors make scholarship recipients looking for other awards that can support his life in France more in the problem of safety that is the essential thing for scholarship recipients to survive and continue his studies.

Based on the failure factor in the funding issue, the Joint Working Group has impacted the declining participants and the interest of students to take the scholarship from the Ministry of Research, Technology, and Higher Education. The results obtained from the Joint Working Group is not following the expected target and do not show an increase in education. But the Joint Working Group must continue to run as the government's efforts can encourage higher education in Indonesia.

Until now, the JWG is still running, which proves Indonesia and France still maintain cooperation in higher education, and this study to continue. Lecturers who do their training in France can implement a learning system in France to students in Indonesia so that universities in Indonesia have an excellent teaching system taken from the French system. The joint study resulted in sharing knowledge to divide and exchange the sciences for the Advancement of society and the impact of social, economic, and cultural to the people of Indonesia by making a quality and beneficial research.

\section{Conclusion}

Education is an important thing that everyone needs to have. The attitude and behavior of someone who follows school are undoubtedly different from those who do not. But unfortunately, not everyone has the awareness to pursue the highest education. For the village community, of course, education is not the main thing; they only prioritize how to survive by relying on its power, not because of its intelligence. For example, a child in a village prefers helping his parents in the field than to wander off as a form to fulfill his life needs. Plus, for them to go to school is a matter of spending money only. Unlike the city people who see so tight the competition to get a job makes one need to go to school and follow the education highest.

Judged from the data described above, the participants who follow the education in Indonesia are getting less each of their crimes (from Elementary, Junior, Senior High School, and College). The government cannot stay silent; efforts are made by the Government to provide assurance of education that can be enjoyed by all elements of society.

At a high level, Indonesia certainly has not been able to subsidize the cost of different lectures in France that prospective students only pay the registration money so that the interest and awareness of higher education in France is higher than in Indonesia. Moreover, when they graduated to become a scholar and to look for a job in France, someone will get placed according to his ability that it can get said that someone who has higher education will be increasinglyappreciated.

To prepare for the era of globalization, Indonesia has entered the ASEAN Economic Society (AEC), which is free trade between countries in South Asia. Indonesia 
must be able to compete with other ASEAN countries to be able to advance the state. Indonesia had good relations for a long time with France, which facilitates the two countries to engage in bilateral relations by making cooperation. Seeing opportunities from France to develop in the field of research and education of the Government of Indonesia through the Ministry of Research, Technology, and Higher Education doing cooperation with the French Embassy because saw that France is a country that has quality technology and education.

The cooperation between Indonesia and France established as a Joint Working Group, which was an annual meeting that began in its meetings, which started at the first encounter on 13 November 2009 in Bali. At the meeting, the two countries talked about the programs that agreed to scholarships at the undergraduate level, masters, and doctors that took place in several applications such as double degree, fast track, and joint research. At the second meeting, they discussed the evaluation of the programs implemented and agreed on the previous session, evaluation in these programs in the form of the addition of the scholarship quota to be given, the addition of period for joint research.

The evaluation conducted on each meeting does not produce that targeted. Participants who receive scholarship funds for students and lecturers have decreased. Of course, it influenced by the existence of factors that inhibit students in conducting their studies in France. One of the factors that are most perceived by the scholarship recipient is that there is a delay in providing funds required by students, such as initial registration fees, housing fees, living allowance, and tuition fees. These costs have been delayed, making the students challenging to fulfill their needs and support during their stay in France because they preceded by the personal money of the scholarship recipients.

With the problems in the management of funds, the Government of that time, namely Susilo Bambang Yudhoyono, made improvements in scholarship funding by creating a new institution that is LPDP with funds managed by the GSA. The funds distributed by the GSA are the lasting funds deposited from $20 \%$ of the budget funds that make LPDP scholarship funds are not dependent on the budget fund. By not connecting it to the State Budget, LPDP scholarship recipients rarely experience a delay in receiving funds as happened in the Ministry of Research, Technology, and Higher Education.

In addition to the difference in disbursement time between the Ministry of Research, Technology, and Higher Education and LPDP, both have some differences between the funding budgets borne by the scholarship recipient. At the LPDP scholarship that provides funds in visa management and provides family funds issued when the scholarship recipient has completed six months of his studies. Unlike the Ministry of Research, Technology, and Higher Education scholarship, which does not cover the visa fee and gives family funds only when the scholarship recipient has three semesters from the study period. Some differences between the two that make the community who intend to seek a scholarship have a scholarship from LPDP that has no quota limit so that the Ministry of Research, Technology gives the learning and Higher Education experienced a decline in fans. Despite the fall of the scholarship, participants provided by the Ministry of Research, Technology, and Higher Education for his graduates who have studied and returned to Indonesia can give influence Indonesia to compete with other human resources that originated from other countries. Although it has a shortage compared with LPDP scholarship but the scholarship offered by the Ministry of Research, Technology, and Higher Education, there is a program aimed at the lecturer because for the award, LPDP not be applied for lecturers. Graduates participated in the research in France, and the scholarships given for lecturers when returning to Indonesia can provide a good influence in 
the form of teaching and learning innovations that given to his students. 


\section{BIBLIOGRAPHY}

\section{Book}

Berridge, G.R., 2002. -Bilateral Diplomacy, Dalam Diplomacy, Theory and Practice, 2nd Edition. New York:Palgrave.

Bogdan, R., \& Biklen s. 1992. Quantitative Research for Education. Boston: Allyn and Bacon.

Cohen, Yoel. 1996. Diplomacy. NJ: Frank Class.

Dam, Sjamsumar dan Riswandi. 1995. Kerjasama ASEAN, Latar Belakang, Perkembangan dan Masa Depan. Jakarta: Ghalia Indonesia.

Djelantik, Sukawarsini. 2008. Diplomasi antara Teori dan Praktik. Yogyakrta: Graha Ilmu.

Holsti, K. J., 1992. International Politics, A Framework of Analysis. New Jersey: Prentice-Hall.

Ikbar, Yanuar. 2012. Metode Penelitian Sosial Kualitatif. Bandung: Refika Aditama.

Mustakim, Bagus. 2011. Pendidikan Karakter ; Membangun karakter emas menuju Indonesia bermartabat. Yogyakarta: Samudra Biru.

Nazir, Moh. 2005. Metode Penelitian. Bogor: Ghalia Indonesia.

O_Neill, Kate. 2009. The Environment and International Relations. New York: Cambridge University Press.

Perwita, Anak Agung Banyu dan Yanyan Mochamad Yani. 2005. Pengantar Hubungan Internasional. Bandung: PT. Remaja Rosdakarya.

Rana, Kishan, S., 2011. In 21st Century Diplomacy A Practitioner's Guide. India: Continuum. Waters, Malcolm. 1996. Globalization. New York: Routledge.

Yusuf, Suffri. 1989. Hubungan Internasional dan Politik Luar Negeri: Sebuah Analisis Teoretis dan Uraian tentang Pelaksanaannya. Jakarta: Pustaka Sinar Harapan.

\section{Journal}

Clinton, W. David Clinton. 1986. The National Interest: Normative Foundations. The Review of Politics. Vol. 48, No. 4.

http://www.jstor.org/stable/1407381?seq=4\#page_scan_tab_contents.

diakses pada tanggal 25 Juni 2017.

Hoed, Benny H. 2008. -Pendidikan di Prancis. Jurnal Kajian Wilayah Eropa. Volume 4 - No. 3.

\section{Document}

1st Final Statement Joint Working Group 2009. 2nd Final Statement Joint Working Group 2010. 3rd Final Statement Joint Working Group 2011. 4th Final Statement Joint Working Group 2012. 5th Final Statement Joint Working Group 2013. 6th Final Statement Joint Working Group 2014. 7th Final Statement Joint Working Group 2015. 8th Final Statement Joint Working Group 2016. 


\section{Internet}

www.batan.go.id

www.beritasatu.com

www.cnnindonesia.com

www.student.cnnindonesia.com

www.edupost.id

www.britannica.com

www.indonesie.campusfrance.org

www.ifi-id.com

www.francealumni.fr

www.sumbarprov.go.id

www.blu.djpbn.kemenkeu.go.id

www.kompasiana.com

www.ppifrance.fr

www.international.sindonews.com www.whitehouse.gov www.tirto.id

www.tnp2k.go.id

\section{Interview}

Edvi. 2017

Hilman, Anton. Institut Francais Indonesia. 2017.

Nurida, Editha. 2017.

Satyandita, Arini. Institut Francais Indonesia. 2017. 